\title{
Multivariate paleoecological analyses of Badenian and Sarmatian molluscan assemblages from the NW Vienna Basin (Rohožník-Konopiská, Slovakia)
}

\author{
Tomáš Fuksi \\ Slovak Academy of Science, Geological Institute; Dúbravská cesta 9, 84005 Bratislava, Slovakia; e-mail: geoltofu@savba.sk \\ (c) 2015 Authors. This is an open access publication, which can be used, distributed and reproduced in any medium according \\ to the Creative Commons CC-BY 4.0 License requiring that the original work has been properly cited.
}

Middle Miocene marine sediments in the Vienna Basin provide opportunities for analyses of spatial and temporal variation in the composition of molluscan communities, especially across the Badenian/Sarmatian boundary. In this study, we describe variation in composition of molluscan assemblages with multivariate analyses (cluster and ordination analyses). In ongoing analyses, we test whether Badenian and Sarmatian assemblages, distinguished on the basis of foraminiferal assemblages by Čierna (1974), significantly differ in their taxonomic and life habit composition.

We focus on a unique set of samples recovered by 80 closely-located borehole cores in 1963 near Rohoznik-Konopiska (Rohalová \& Hash 2000), penetrating to $\sim 30-100 \mathrm{~m}$ depth in the western part of Slovakia. These cores capture sediments of the Studienka (Badenian) and Holíc (Sarmatian) formations that consist of clays, sands and silts. Čierna (1974) studied foraminiferal assemblages in these cores and found that they correspond mainly to the Upper Badenian and Sarmatian. The boundary between the Badenian and Sarmatian sediments is located at 206 m.a.s.l. in the SW part and at $\sim 180$ m.a.s.l. in the NE part of the study area. Diverse molluscan assemblages in this area were described by Švagrovský $(1971,1981)$, Mesároš (1986) and Hladilová (1991).

A well preserved shelly material from 80 borehole cores of Rohožník contains presently more than 6000 individuals (mainly of Badenian age), with ongoing screening of additional samples. They correspond to 156 gastropod, bivalve, and scaphopod taxa at species and genus-level resolution. 72 samples were subjected to preliminary multivariate analyses in the $\mathrm{R}$ language. A cluster analysis is based on a Bray-Curtis distance and square-root transformed proportional abundances. Ordination analyses are represented by non-metric multidimensional scaling and by principal coordinate analysis.

The cluster analysis discriminated five major sample groups with a recurrent taxonomic composition, although ordination analyses show that some of these groups do not form discrete clusters in a multivariate space but rather continuously grade into each other. Mohrensternia sp. and Bittium reticulatum are dominant in the first group. These taxa represent herbivorous euryhaline gastropods, which preferred muddy bottoms (Švagrovský 1971, Kowalke \& Harzhauser 2004). Nassarius illovensis, Acteocina lojankeriana, Nuculana fragilis and Clithon pictus dominate in the second group. $N$. fragilis represents an infaunal, mobile, asiphonate deposit-feeder; gastropods are represented by mobile taxa with different food requirements that lived in photic zone (Leonard-Pingel et al. 2012). The third group is dominated by Corbula gibba and Nucula nucleus. C. gibba and N. nucleus represent opportunistic bivalve species that indicate 
unstable habitats with muddy bottoms, frequently characterized by low-oxygen concentrations and by organic enrichment (Holmes 2002, Hrs-Brenko 2006, N'Siala et al. 2008). The fourth group is dominated by Alvania curta, accompanied with Amalda gladiformis, Cerithium europaeum, and by Aporrhais pespelecani and Acanthocardia turonica that occur exclusively in the Badenian (Harzhauser \& Piller 2007, Studencka \& Popov 1996). A. turonica prefers sandy bottom, gastropods are represented by herbivore taxa (Švagrovský 1981, Studencka 1986). The fifth group can be characterized as Diloma and Cerithium-dominated association. It mainly consists of gastropods. Diloma occurs in sandy littoral environments (Kroh \& Harzhauser 1999). This discrimination of samples fits with the result of principal coordinate analysis where these taxa group similarly.

Associations of molluscs indicate that sedimentation occurred in the photic zone because the determined molluscs predominantly occupied to shallow subtidal environments. The high abundance of Corbula gibba and Nucula nucleus shows a presumption of stratification of water column, with low content of $\mathrm{O}_{2}$ on the bottom. Some samples in the uppermost parts of cores imply brachyhaline conditions.

\section{REFERENCES}

Čierna E., 1974: Micropaläontologische und Biostratigraphische Untersuchung eininger Bohrproben aus der weiteren Umgebung von Rohožník. Acta Geologica et Geographica Universitatis Comenianae. Geologica, 26, 113-187.

Kowalke T. \& Harzhauser M., 2004. Early ontogeny and paleoecology of the Miocene rissoid gastropods of the Central Paratethys. Acta Palaeontologica Polonica, 49; 111-134.

Harzhauser M. \& Piller W.E., 2007. Benchmark data of a changing sea palaeogeography, palaeobiogeography and events in the Central Paratethys during the Miocene. Palaeogeography Palaeoclimatology Palaeoecology, 253, 8-31.

Hladilová Š., 1991. Results of preliminary studies of the moluscan fauna from Rohožník locality. Scripta Facultatis Scientiarum Naturalium Universitatis Masarykiance Brunensis. Geology, 21, 91-97.

Holmes P.S., Miller N. \& Anke Weber A., 2002. The respiration and hypoxic tolerance of Nucula nitidosa and $\mathrm{N}$. nucleus: factors responsible for determining their distribution? Journal of the Marine Biological Association of the UK, 82, 971-981.

Hrs-Brenko M., 2006. The basket shell, Corbula gibba Olivi, 1792 (Bivalve Mollusks) as a species resistant to environmental disturbances: A review. Acta Adriatica, 47, 49-64

Kroh A. \& Harzhauser M., 1999. An echinoderm fauna from the Lower Miocene of Austria: paleoecology and implications for central Paratethys paleobiogeography. Annalen des Naturhistorischen Museums in Wien, 101, 145-191

Leonard-Pingel J.S., Jackson J.B.C. \& O'Dea A., 2012. Changes in bivalve functional and assemblage ecology in response to environmental change in the Caribbean Neogene. Paleobiology, 44, 509-524.

Meszároš Š., 1986. Anomálie schránok mäkkýšov z vrchnobádenských sedimentov lokalít okolia Malých Karpát. Západné Karpaty, séria Paleontológia, 11, 57-76.

Massamba N'Siala G., Grandi V., Iotti V., Montanari G., Prevedelli D. \& Simonini R., 2008 Responses of a northern Adriatic Ampelisca-Corbula community to seasonality and short-term hydrological changes in the Po river. $\mathrm{Ma}$ rine Environmental Research, 66, 466-476.

Rohalová M. \& Hash J., 2000. Záverečná správa: Rohožník-Konopiská, tažobný prieskum, Hirocem.

Studencka B., 1986. Bivalves from the Badenian (Middle Miocene) marine sandy facies of southern Poland. Palaeontologia Polonica, 47, 1-128.

Studencka B. \& Popov S.V., 1996. Genus Acanthocardia (Bivalvia) from the Middle Miocene of the Paratethys. Prace Muzeum Ziemi, 43, 17-37.

Švagrovský J., 1971. Das Sarmat der Tschechoslowakei und seine Molluskenfauna. Acta Geologica et Geografica Universitatis Comenianae. Geologica, 20, 1-473.

Švagrovský J., 1981. Lithofazielle Entwicklung und Molluskenfauna des oberen Badeniens (Miozän M4d) in dem Gebiet Bratislava - Devínska Nová Ves. Západné Karpaty, séria Paleontológia, 7, 5-204. 